\title{
検出器感度ばらつきの推定によるリニアアレイセンサ 画像の強度補正法
}

\author{
本間 弘 一*・坪井晃**・古村 文 伸*
}

\author{
A Radiometric Correction Method of Linear-Array-Sensor Image \\ by Estimating Variations of Detector Characteristics
}

Koichi Homma*, Akira Tsubor** and Fuminobu KomurA*

\begin{abstract}
A radiometric correction method for linear array sensor image is proposed. This method removes stripe noise pattern caused by the errors of detector characteristics of the sensor. In this method, mean and variance of output image are calculated for each detector. Highpass filters are applied to the statistics to estimate gain and offset errors of the detectors.

In this paper, power spectra of mean and variance of each detector are studied by assuming a 2-dimensional auto-correlation model for the original image. Based on the power spectrum models of the statistics, Wiener filters (least square filters) are derived. In the method the filter parameters are determined adaptively by the sensor image.

An experiment was made by simulating image of linear array sensor using a LANDSAT image. The stripes were removed in the corrected image and the decrease of the rms error of the image intensity showed the effectiveness of the method.
\end{abstract}

Key Words : linear array sensor, image processing, Wiener filter, radiometric correction, auto-correlation

\section{1.はじめに}

リニアアレイセンサとは，1列に並んだ多数の検出 器からなり, 1 ライン分の画像を同時に入力する撮像

* (株) 日立製作所システム開発研究所 川崎市麻生区王禅寺 1099

**（株）日立メディコ大阪工場 柏市新十余二 2 の 1

* Systems Development Laboratory, Hitachi, Ltd. Kawasaki

** Hitachi Medical Corporation, Kashiwa (Received September 9, 1985)

(Revised January 10, 1986)
センサである.リニアアレイセンサは，ラインに沿っ た方向の機械的走査機構がいらないなどの利点をもつ ため，リモートセンシング1),2)を始め, 多くの画像入 カシステムで用いられている：とてろで, 検出器の間 に感度特性のばらつきがある場合には，画像に縞状の 濃淡ノイズが重冨し画質を劣化させる. 画像の濃焱ノ イズを除去することは，幾何学的歪みの補正 ${ }^{3), 4)}$ 之並 び, 観測画像からの正しい情報抽出にとって, 重要で ある. ノイズ除去の一般的画像処理方式としては, 特 定周波数成分除去のフィルタ处理 ${ }^{5)}$ ，画像実空間での 平滑化処理6)，スパイク状ノイズの置き換え処理 ${ }^{7)}$, などがある.一方, ノイズの発生機構を考慮した補正 方式としては, 基準光源による検出器の校正 ${ }^{8)}$, 撮像 画像による感度ばらつきの推定 ${ }^{9}$ ，などの方式がある. 後者は, 校正に誤差を生ずる場合, 温度などの環境条 件の変化により検出器感度のばらつき特性が変化する 場合, 校正を省略したい場合などに必要となる.

本論文は，撮像画像を用いた感度ばらつきの推定に よる,リニアアレイセンサ画像の強度補正方式に関す るあのである.

従来, 複数の検出器の感度特性のぼらつきを撮像画 像から推定する手法は, 衛星搭載センサである MSS (Multi-Spectral Scanner) の画像に対し用いられてい $ろ^{99}$. 本手法では, 各検出器について画像データの頻 度分布を求め, それらのばらつきから, 検出器感度の ばらつきを推定する. MSS センサでは, 少数の検出 器により 1 画面あたり数干ラインの繰返し走查を行う ため, 各検出器に対する原画像の頻度分布は, 等しい とみなせるからである、筆者らは, リニアアレイセン サに対して屯, 検出器別の画像データの平均や分散は 検出器間でゆっくり変化するという前提で, それらの 急激な变化をフィルタで分離し, 検出器感度のばらつ 
きに帰す方式を提案してきた ${ }^{10}$. しかし，上記前提の 平滑さが，画像の性質之統計計算に用いる画像ライン 数に応じて，ぞう変化するか明らかにされておらず， フィルタ形状の決定法が得られていないという問題が あった。

本論文では, まず検出器ごとの統計量の急激な変化 から検出器感度のばらつきを推定するリニアアレイ センサ画像強度補正方式の基本的考え方を示す.つぎ に, 検出器別の画像統計量の空間周波数特性を, 画像 の 2 次元相関特性をモデル化し検討する．その結果を あとに，ウィーナーフィルタによる 2 乘誤差最小な検 出器感度ばらつきの推定について述べ，推定精度につ いてあ検討する. 最後に, 撮像画像自身からフィルタ 形状を適応的に決定する方式を提案する. 模擬画像を 用いた補正実験の結果加ら，提案方式の有効性を示 す.

\section{2. 画像強度補正方式}

\section{1 リニアアレイセンサ画像}

リニアアレイセンサによる撮像系の一つの例とし て, 衛星による地球钼測システムを, Fig. 1 亿示す. 直線上に並んだ多数の検出器は，センサを搭載した衛 星の移動に合せ，1ラインずつの画像データを入力す る. 複数の検出器に感度特性のばらつきが存在する 之, 出力画像上にリニアアレイセンサと垂直方向の 縞状のノイズが現れる. 仏 SPOT 衛星搭載の CCD (Charge Coupled Device) リニアアレイセンサの一様 光源に対する出力測定值例では, $1.5 \%$ 程度の検出器 感度ばらつきが報告されている11.

Fig. 1 に示すように, $k$ 番目の検出器に関する $j$ ライン目の出力画像强度を $x^{\prime}(j, k)$, 原画像すなわち

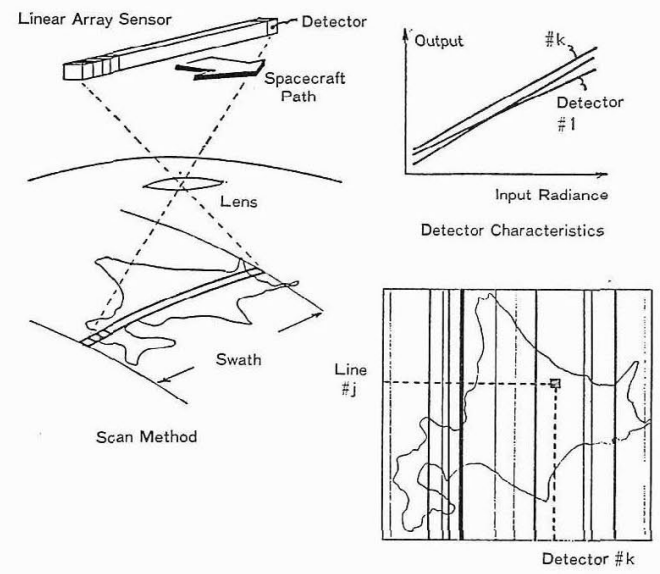

Fig. 1 A linear array imaging system and stripe noises on the image
検出器の理想大出力特性を仮定した出力画像の強度を $x(j, k)$ とする. 各恮出器の実際の特性が，理想的特 性からばらつく量は微小であるため, 出力画像 $x^{\prime}(j$, $k)$ は, 各检出器に関する次線形式で表わせる。

$$
\begin{aligned}
& x^{\prime}(j, k)=a(k) x(j, k)+b(k) \\
& a(k) \sim 1, \quad b(k) \sim 0
\end{aligned}
$$

ここで, $a(k), b(k)$ は $k$ 番目の検出器の特性のばらつ き，すなわちゲイン誤差とオフセット誤差を表わす。 $k$ 番目の検出器に関する $N$ ライン分の出力画像の平均 $m^{\prime}(k)$ と分散 $\sigma^{2 \prime}(k)$ は,

$$
\begin{aligned}
m^{\prime}(k) & =\frac{1}{N} \sum_{j=1}^{N} x^{\prime}(j, k) \\
& =a(k) m(k)+b(k) \\
\sigma^{2 \prime}(k) & =\frac{1}{N} \sum_{j=1}^{N}\left\{x^{\prime}(j, k)-m^{\prime}(k)\right\}^{2} \\
& =a(k)^{2} \sigma^{2}(k)
\end{aligned}
$$

となる. $m(k), \sigma^{2}(k)$ は, 原画像の平均と分散である. 実際の撮像画像の一例として Photo. 1 亿示す, ラン ドサット衛星の MSS 画像について, 画像強度をたて

Photo. 1

Example of image data
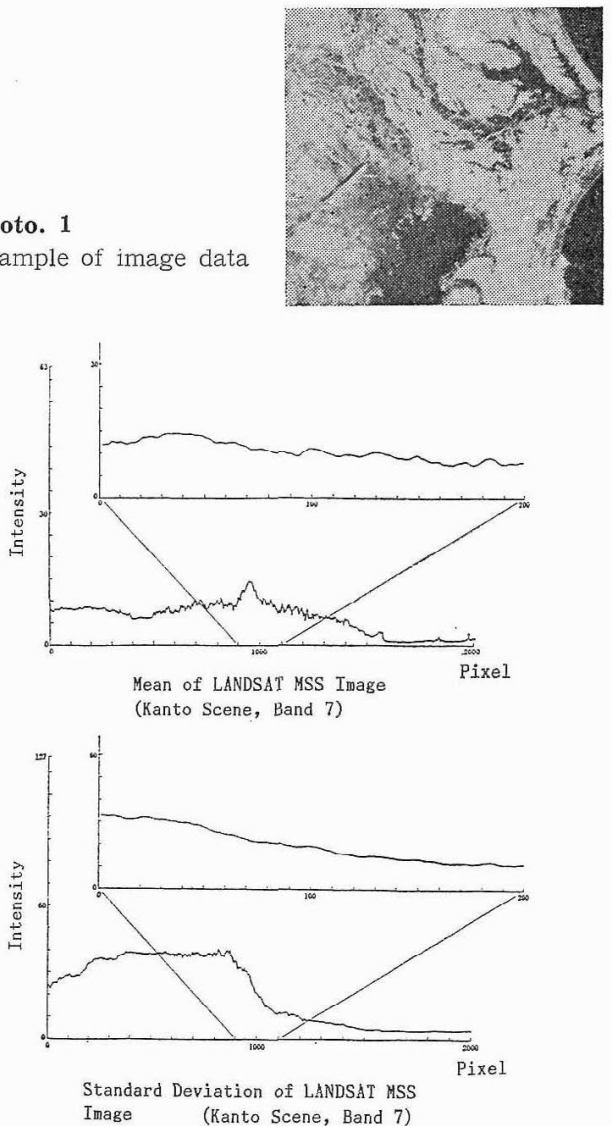

Fig. 2 Statistics of image intensity of Photo. 1 on vertical lines 
方向に足し込み, 平均, 標準偏差を求め, Fig. 2 亿 プロットする. 平均 $m(k)$ と分散 $\sigma^{2}(k)$ は, 検出器番 号 $k$ に関して急激には変化しないととがわかる. 統計 計算に用いるライン数 $N$ が大きいほど, 乙の変化は滑 らかになるといえる. したがって, 出力画像 $x^{\prime}(j, k)$ の平均 $m^{\prime}(k)$, 分散 $\sigma^{2 \prime}(k)$ の $k$ 亿対する変動の高周波 成分は, 検出器の感度誤差 $a(k), b(k)$ が原因であると 考え, てれらを高域ろ過フィルタにより求めることが できる.

ところで, 検出器感度誤差を, 出力画像の検出器別 画像統計量汃ら, 高域ろ過フィルタにより求めるため には, 検出器別画像統計量の周波数特性を明らかに し，その結果を用いてフィルタ形状を決めることが 必要である. 特に, 検出器別画像統計量の周波数特性 は, 画像の統計的性質と, 統計量計算に用いるライン 数Nに依存するため, それらをパラメータとしたモデ ル化が必要である.

\section{2 検出器別画像統計量の特性}

画像の 2 次元自己相関関数の統計的モデルから, 画 像データ $N$ ライン分の平均值の 1 次元自己相関関数を 求める. $k$ 番目の検出器に関する原画像強度を $x(j$, $k), N$ インの平均をあらためて $\bar{x}^{N}(k)$ と表わすと,

$$
\bar{x}^{N}(k)=\frac{1}{N} \sum_{j=1}^{N} x(j, k)
$$

である. 2 次元自己相関関数 $R(j, k)$ の定義,

$$
R(j, k)=E\{x(s, t) x(s+j, t+k)\}
$$

を用いて, $N$ ライン平均值の 1 次元自己相関関数 $R_{N}$ (k) を変形すると,

$$
\begin{aligned}
R_{N}(k) & =E\left\{\bar{x}^{N}(t) \bar{x}^{N}(t+k)\right\} \\
& =\frac{1}{N^{2}} \sum_{i=1}^{N} \sum_{j=1}^{N}\{E\{x(i, t) x(j, t+k)\} \\
& =\frac{1}{N^{2}} \sum_{i=1}^{N} \sum_{j=1}^{N} R(j-i, k) \\
& =\sum_{j=-N+1}^{N-1} \frac{N-|j|}{N^{2}} R(j, k)
\end{aligned}
$$

となる. こてで, $E\{\}$ は期待值を表わす.

一般に，画像の 2 点間の相関は，方向によらず， 2 点間の距離に応じて単調に減少する ${ }^{12)}$. したがって, 入力画像強度の 2 次元自己相関関数 $R(j, k)$ は, 原点 で最大值をむち, 原点からの距離に応じて単調に減少 する関数となる.（6)式はこのような性質の関数 $R$ $(j, k)$ を, Fig. 3 亿模式的に示すように三角形の荷重 関数を乗じ一方向に加算するてとを意味する. 一段に 1 次元自己相関関数 $R_{N}(k)$ は, やはり単調減少関数 となる。

相関関数 $R(j, k)$ のモデルとして, 指数関数的に減

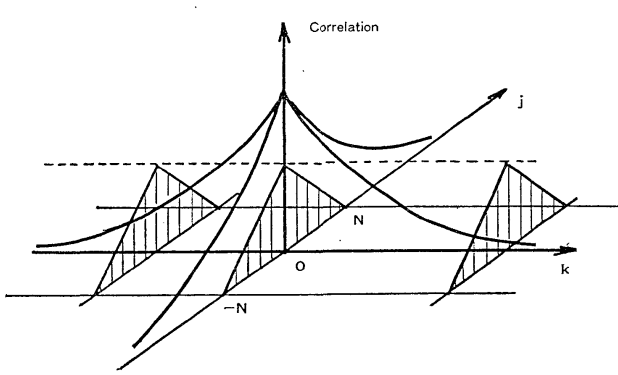

Fig. 3 Weighted averaging of two dimensional auto-correlation function

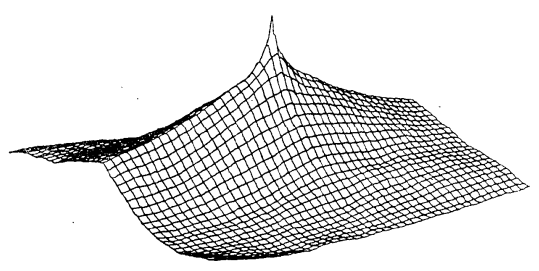

Fig. 4 Two dimensional auto-correlation function of Photo. 1

少する $(7)$ 式を具体的に与え, $N$ ライン平均値の 1 次 元自己相関関数 $R_{N}(k)$, およびそのフーリエ変換であ るパワースペクトルを求める. なお, 関数は簡単のた め, 变数 $j, k$ に関し分離できるむのとしている. $\alpha, \beta$ は減衰係数, $K$ は定数である.

$$
R(j, k)=K \exp (-\alpha|j|) \exp (-\beta|k|)
$$

指数関数的に減少する相関関数は, マルコフ過程モデ ルに基づくもので，画像を統計的に扱う場合によく 用いられる ${ }^{122}$. 実際の画像データ Photo. 1 について 屯, Fig. 4 亿示すように, 相関関数の指数関数的減 少を見ることができる.（7)式を(6)式代入する と, $N$ ライン平均值の自己相関関数 $R_{N}(k)$ は, $r=\exp$ $(-\alpha)$ として,

$$
R_{N}(k)=K\left[\frac{1}{N}\left\{\frac{1+r}{1-r}\right\}+\frac{2}{N^{2}} \frac{\left(r^{N+1}-r\right)}{(1-r)^{2}}\right] \exp (-\beta|k|)
$$

と求まる. 係数より, ライン数 $N$ が十分大きい場合に は, 関数全体が $1 / N$ に比例して減少するてとがわか る. また, $\exp (-\alpha)$ が 1 亿近い程，すなわち， $j$ 軸の 方向の相関が強い程, その隇少はゆるやかとなる.し たがって，(8)式をフーリエ変換して得られるパワー スペクトラム $\operatorname{Pm}(v)$ あライン数 $N$ について同様の性 質をあち,

$$
P m(v)=\frac{K m}{\left(v^{2}+\beta^{2}\right) N}
$$

となる. $K m$ は定数, vは空間周波数である.

各検出器に関する画像 $N$ ライン分の分散值の 1 次元 
自己相関関数についても, 原画像に $(7)$ 式の自己相関 関数を仮定して求めることができる.とこでは，画像 強度 $x(j, k)$ の代わりに, その 2 乗值 $\{x(j, k)\}^{2}$ を考 える. 2 乗画像の自己相関関数 $R_{2}(j, k)$ は, 4 次の項 の期待值の関係式 ${ }^{13)}$ より,

$$
R_{2}(j, k)=\{R(0,0)\}^{2}+2\{R(j, k)\}^{2}
$$

と表わせる. したがって, パワースペクトラム $P \sigma^{2}(v)$ の形状は, 平均値亡同様 $K \sigma^{2}$ を定数として,

$$
P \sigma^{2}(v)=\sigma_{0}^{2} \delta(v)+\frac{K \sigma^{2}}{\left(v^{2}+4 \beta^{2}\right) N}
$$

となる. $\delta(v)$ は, デルタ関数である.

\section{3 ウィーナーフィルタによる感度誤差の推定}

リニアアレイセンサ画像の, 検出器別画像統計量の 関係式 (2), (3) 式において, 原画像の統計量 $m(k)$, $\sigma^{2}(k)$ の周波数特性を既知とし, 検出器誤差 $a(k), b(k)$ を 2 乗誤差最小の意味で最適に推定する.

まず,（3)式から検出器ゲイン $a(k)$ を推定する. 検出器ゲイン誤差 $\Delta a(k)$ を $\Delta a(k)=a(k)-1$ にり定 義し, また, 分散 $\sigma^{2}(k)$ をバイアス成分 $\sigma_{0}^{2}$ 亡変化成 分 $\sigma_{+}^{2}(k)$ に分離し, $\sigma^{2}(k)=\sigma_{0}^{2}+\sigma_{+}^{2}(k)$ と表わす. 通常 ゲイン誤差 $\Delta a(k)$ は, 設定ゲイン 1 に比べ十分小さ

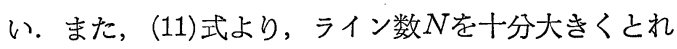
ば，バイアス成分 $\sigma_{0}^{2}$ が一定であるのに比べ, 変化成 分 $\sigma_{+}^{2}(k)$ は $N^{-1}$ のオーダーで減少する. そこで,

(3) 式を,

$$
\sigma^{2 \prime}(k)=\sigma_{0}^{2}+\sigma_{+}^{2}(k)+2 \sigma_{0}^{2} \Delta a(k)
$$

之線形化する. 検出器ゲイン $a(k)$ を求めるためには, 出力画像の検出器ごとの分散值 $\sigma^{2 \prime}(k)$ から右辺第 3 項 の $\Delta a(k)$ を推定すればよい. 一般に, 他の雑音信号と 加算された信号を，2乗誤差最小で推定する演算は, ウィーナーフィルタで実現できる ${ }^{14)}$. そこで, 検出器 ゲイン誤差 $\Delta a(k)$ の推定は, 以下の演算となる。

$$
\begin{aligned}
& \Delta \hat{a}(k)=\frac{1}{2 \sigma_{0}^{2}} F^{-1}\left[H \sigma^{2}(v) F\left\{\sigma^{2 \prime}(k)\right\}\right] \\
& H \sigma^{2}(v)=1-P \sigma^{2}(v) / P \sigma^{2 \prime}(v) \\
& \text { ただし, } H \sigma^{2}(0)=0
\end{aligned}
$$

ここで, $F\left(^{-1}\right)$ はフーリエ(逆)変換を, Hはフィルタ 係数を, 記号へは推定值であることを表わす.つぎ に，(12)式を変形した，

$$
\begin{aligned}
& \frac{m^{\prime}(k)}{\hat{a}(k)}=m(k)+\frac{b(k)}{\hat{a}(k)} \\
& \text { ここで, } \hat{a}(k)=\Delta \hat{a}(k)+1
\end{aligned}
$$

に対し，(13)式と同様のウィーナーフィルタを用い る.すなわち,

$$
\begin{aligned}
& \hat{b}(k)=\hat{a}(k) F^{-1}\left[H m(v) F\left(\frac{m^{\prime}(k)}{\hat{a}(k)}\right)\right] \\
& H m(v)=1-P m(v) / P m^{\prime} / a(v)
\end{aligned}
$$

\section{と,オフセット $b(k)$ を推定できる.}

(13), (15)式で, 各検出器のゲイン, オフセットの 推定值 $\hat{a}(k), \hat{b}(k)$ を求めた後, 出力画像 1 画素ごと に, 次式で補正画像 $\hat{x}(j, k)$ を求め, 検出器感度誤差 による出力画像上のノイズを除去する.

$$
\hat{x}(j, k)=\left\{x^{\prime}(j, k)-\hat{b}(k)\right\} / \hat{a}(k)
$$

\section{4 フィルタ形状の検討と推定精度の評価}

ウィーナーフィルタ (13), (15) 式の関数形状を(7) 式の画像相関モデルに基づいて検討する.

まず，原画像に対する検出器別統計量の，空間周波 数特性 $P m(v), P \sigma^{2}(v)$ を（9)，(11)式で与える. つぎに, ノイズを含む画像の検出器別統計量の周波数 特性 $P m^{\prime}(v), P \sigma^{2 \prime}(v)$ を, 検出器誤差 $\Delta a(k), b(k)$ は 無相関の白色雑音であると考え, (9), (11)式に, 周 波数 とする.

したがって，たとえば平均值に関するウィーナーフ ィルタの形状は，(15)式より，

$$
H m(v)=\frac{v^{2}+\beta^{2}}{v^{2}+\left(K m / N n_{m}^{2}+\beta^{2}\right)}
$$

となる・

周波数特性 $P m(v), n_{m}^{2}$, フィルタ $H m(v)$ の形状を 模式的に Fig. 5 に示す. 乙れらの模式的関係は，検 出器別分散を用いた，ゲイン誤差の推定に関しても同 様に成り立つ. 検出器䛠差の高い周波数成分は精度よ く推定できるが, 低い周波数については精度が下がる. パーシバルの定理から, 各検出器誤差の推定誤差 2 乗 和は, Fig. 5 の斜線部分の面積 $S$ に比例するととがい える. 統計量を求めるライン数 $N$ をきくすると, フ ィルタ值が $1 / 2$ となる周波数 $v c$ は小さくなり, 推定 誤差を表わす面積 $S$ は，ライン数 $N$ の $1 / 2 \sim 1$ 乗に比 例して減少する.

\section{5 撮像画像を用いたフィルタの設計}

撮像画像, すなわち補正すべき画像自身を用いて, (13), (15)式のウィーナーフィルタの形状を決定す る.

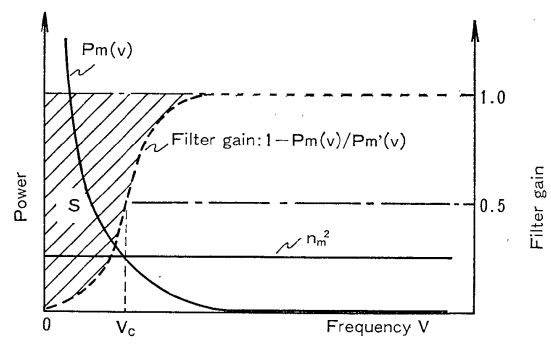

Fig. 5 Wiener filter to estimate detector errors 
ウィーナーフィルタ式において, 検出器感度のばら つきによるノイズを含む画像に対する検出器別の分 散, 平均の周波数特性 $P \sigma^{2 \prime}(v), \mathrm{Pm}^{\prime}(v)$ は, 出力画像 $x^{\prime}(j, k)$ の分散 $\sigma^{2 \prime}(k)$, 平均 $m^{\prime}(k)$ のフーリエ変換加 ら推定できる，しかし，ノイズを含まない画像に対す る周波数特性 $P \sigma^{2}(v), P m(v)$ を, 出力画像から直接 推定することはできない，そこで，原画像の 2 次元周 波数特性の空間連続性を利用し間接的に推定を行う. 検出器ごとの平均值の周波数特性は，2 次元フーリエ 変換の定義から明らかなように，原画像の 2 次元周波 数特性の $v$ 軸 $(u=0)$ 上の断面であり, 原点付近を除

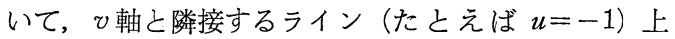
の断面とほぼ等しい. 分散值に対しても, 分散画像 $\{x(j, k)-m(k)\}^{2}$ について同様の乙とがいえる. 2 次 元周波数特性の $(u=-1)$ 上の周波数特性は, 荷重計 算による分散と平均,

$$
\sigma_{1}^{2}(k) \triangleq \frac{1}{N} \sum_{j=1}^{N}\{x(j, k)-m(k)\}^{2}\left\{\cos \frac{2 \pi}{N} j+i \sin \frac{2 \pi}{N} j\right\}
$$

$$
m_{1}(k) \triangleq \frac{1}{N} \sum_{j=1}^{N} x(j, k)\left\{\cos \frac{2 \pi}{N} j+i \sin \frac{2 \pi}{N} j\right\}
$$

の, 1 次元パワースペクトラム $\left|F\left[\sigma_{1}^{2}(k)\right]\right|^{2}, \mid F\left[m_{1}\right.$ $(k)]\left.\right|^{2}$ により推定できる.

ところで，原画像に対する荷重計算による平均，分 散は実際に計算することはできないが，ノイズを含む 出力画像 $x^{\prime}(j, k)$ に対する, 同一の荷重計算による分 散 $\sigma_{1}^{2 \prime}(k)$ は求めることができる. 両分散の間には,

$$
\begin{aligned}
\sigma_{1}^{2 \prime}(k) & \triangleq \frac{1}{N} \sum_{j=1}^{N}\left\{x^{\prime}(j, k)-m^{\prime}(k)\right\}^{2}\left\{\cos \frac{2 \pi}{N} j+i \sin \frac{2 \pi}{N} j\right\} \\
& =(1+\Delta a(k))^{2} \sigma_{1}^{2}(k)
\end{aligned}
$$

の関係が成り立つ. いま, ゲイン誤差 $\Delta a(k)$ は 1 に比 べ, 十分小さい白色雑音であり, また推定したい值自 身であるため, フィルタ中の周波数特性 $P \sigma^{2}(v)$ の推 定には, 分散 $\sigma_{1}^{2}(k)$ のパワースペクトラムのかわりに, $\sigma_{1}^{2 \prime}(k)$ のパワースペクトラムをそのまま用いる，また， 荷重計算による出力画像の検出器別平均值 $m_{1}^{\prime}(k)$ は,

$$
m_{1}^{\prime}(k)=a(k) m_{1}(k)
$$

と表わされ，ゲインの推定值 $\hat{a}(k)$ で除すととにより， $m_{1}(k)$ を推定できる. そこで, 周波数特性 $\operatorname{Pm}($ v $)$ の推 定には $m_{1}^{\prime}(k) / \hat{a}(k)$ のパワースペクトラムを用いる.

なお, 通常分散值を求める際, 計算処理システム上 では， 2 乗平均值から平均值の 2 乗を引くことによ り，全画像データの記憶と繰返しの読み出しを避ける ように，(18)式の荷重計算による分散值も，2 乗值の 荷重平均と, 荷重計算による平均値をむとに効率的に 計算することができる.

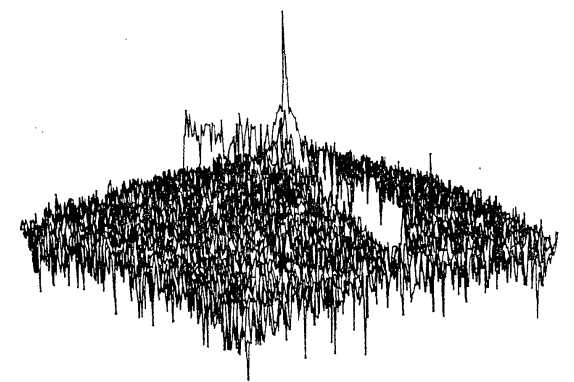

Fig. 6 Two dimensional power spectrum of image data with random stripes

以上により，検出器感度のばらつきによるノイズを 含む出力画像 $x^{\prime}(j, k)$ から，ノイズを含まない原画像 $x(j, k)$ に対する検出器ごとの統計量の周波数特性を 推定できた，なお，実際の画像データをフーリエ変換 して求めた 2 次元パワースペクトラムは, 滑らかでは ない.したがって，v軸上でのパワースペクトムと隣 接ライン上のパワースペクラムからフィルタ式に従っ て得られる，ウィーナーフィルタの形状も滑らかでは ない，そとで，前節の統計モデルに基づくフィルタ形 状 (17)式を最小 2 乗法によりあてはめ, 滑らかなフィ ルタ形状を求める.

Photo. 1 の画像に加算的縞状ノイズを加え，2次 元パワースペクトラムを求めた例を, Fig. 6 に示す. 縞状ノイズは， $u$ 軸上でつい立状に分布する. 乗算的 縞状ノイズあ微小であれば，2 乗画像のパワースペク トラム上で同様の分布を示す. 提案強度補正手法は, Fig. 6 亿示す顕著なノイズ成分を周囲のパワースペク トラムから補間し，ノイズの低減を図るあのであると あ解釈できる．ただし，膨大な 2 次元フーリエ変換， 逆変換演算を要しないとと, 統計モデルを用い補正精 度の向上を図れることが，提案手法の特徽である.

\section{3. 画像補正実験}

検出器感度詥差を含むりニアアレイセンサ画像を， ランドサット衛星の MSS 画像データから模擬的に作 り，提案方式による補正実験を行った．使用した MSS 画像は Photo. 1 に示したあのである. 画像のデータ 点数は，たて横 2048 であり， 1 画素 128 レベルであ る. Photo. 2 に, リニアアレイセンサの検出器感度む らを模擬して得た画像の一部を，拡大して示す。たて 方向にランダムな縞模様が重畳している. 比較的高レ ベルの画像強度をもつ陸域を強調し (a) に，低レベル の海域の縞模様を強調し ( b ) に示す. なお, 検出器の ゲイン $a(k)$, オフセット $b(k)$ の值は, 平均 1.0 標準 偏差 0.02 , 平均 0.0 標準偏差 2.0 の白色雑音とした. 
まず, Photo. 2 の画像データ $x^{\prime}(j, k)$ に対し, 検 出器でとの平均值 $m^{\prime}(k)$, 分散值 $\sigma^{2 \prime}(k)$ と, (18), (19)式の荷重計算による平均伹 $m_{1}^{\prime}(k)$ ，分散値 $\sigma_{1}^{2 \prime}(k)$ を求める. つぎに, 検出器ゲイン䛊差を推定するた め, 分散値 $\sigma^{2 r}(k), \sigma_{1}^{2 \prime}(k)$ 上り(13)式のウィーナーフ

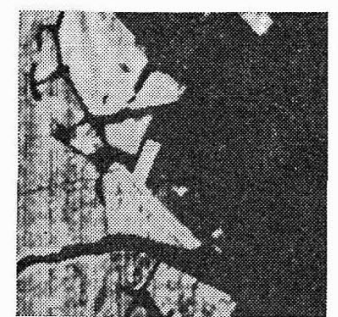

(a) the higher level contrast is enhanced

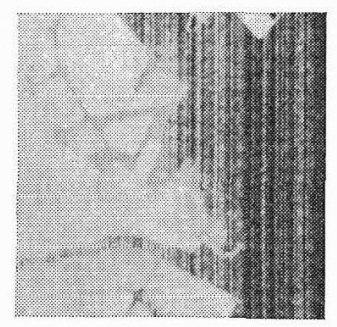

(b) the lower level contrast is enhanced
Photo. 2 Simulated linear array image with stripe noises. An area in Photo. 1 is enlarged to show the stripes.

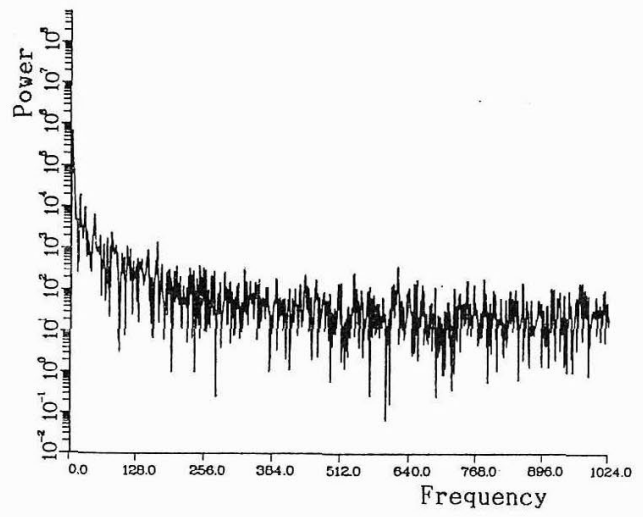

(a) power spectrum of variance $\sigma^{2}(k)$

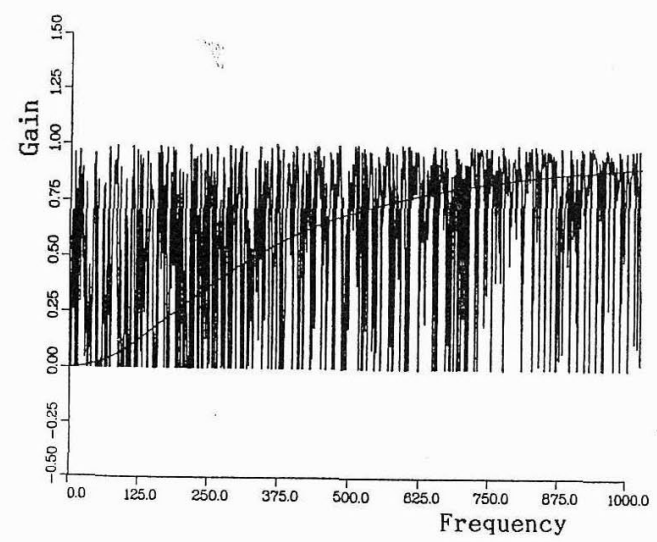

(c) Wiener filter
ィルタの演算を行う. Fig. 7(a)，（b）に，それぞれ の分散值のパワースペクトラムを示す. Fig. 7(a)は ノイズを含む画像化対する検出器別分散值の周波数特 性 $P \sigma^{2 \prime}(v)$, 同図 (b) は八イズのない原画像に対する同 周波数特性 $P \sigma^{2}(v)$ の推定值として用いられる. (13) 式のフィルタ形状 $H \sigma^{2}(v)$ を, 同図 (c) に示す. 前述 の統計モデルに基づく関数を最小 2 乗法であてはめ。 平滑化したフィルタ形状屯示す. Fig. 7(d)は，(13) 式により推定した検出器ゲイン $\hat{a}(k)=(1+\Delta \hat{a}(k))$ を 真のゲイン $a(k)$ と比較し検出器 $k=1 \sim 120$ について 示したものである.

つぎに, 検出器オフセットを平均值 $m^{\prime}(k), m_{1}^{\prime}(k)$ より推定する. ただし, 平均值 $m^{\prime}(k)$ については, 検 出器ゲインの推定值 $\hat{a}(k)$ により除しておく. Fig. 8 は, Fig. 7 に対応するものである. 検出器別平均值 のパワーが，比較的小さい空間周波数から，ノイズの パワー上り小さくなるため。フィルタ形状の立ち上が

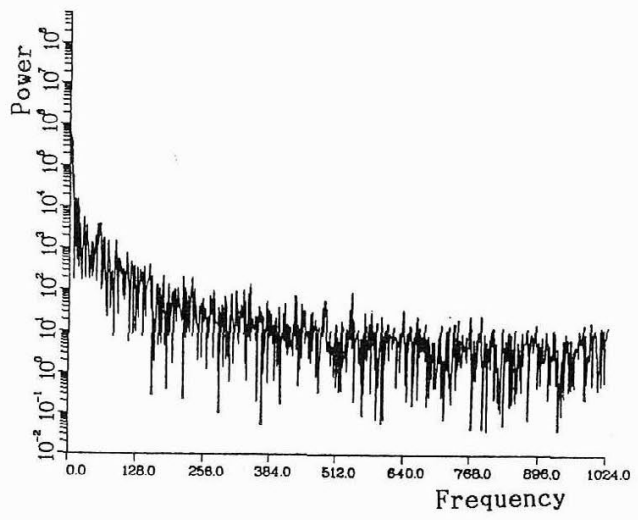

(b) power spectrum of weighted variance $\sigma_{1}{ }^{2}(k)$

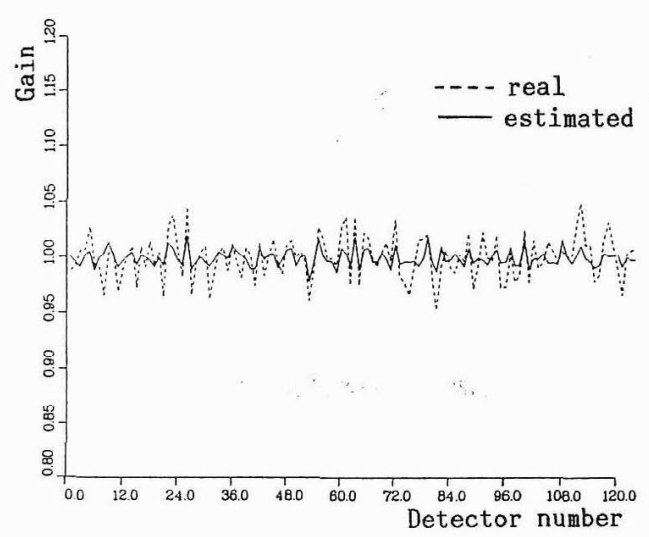

(d) estimated detector gain

Fig. 7 Estimation of detector gain. 


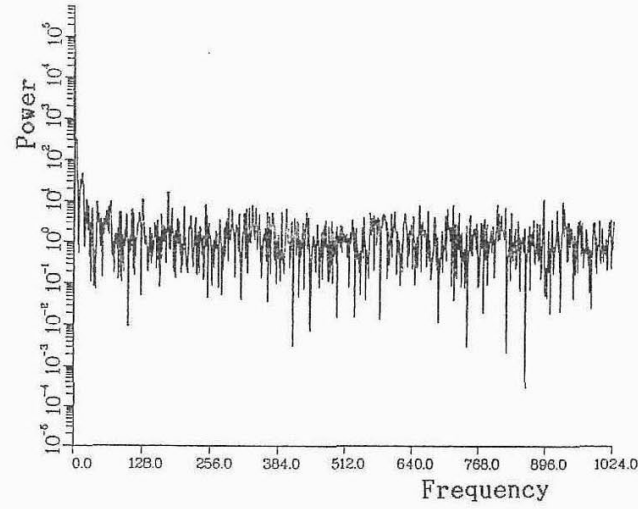

(a) power spectrum of mean $m^{\prime}(k)$

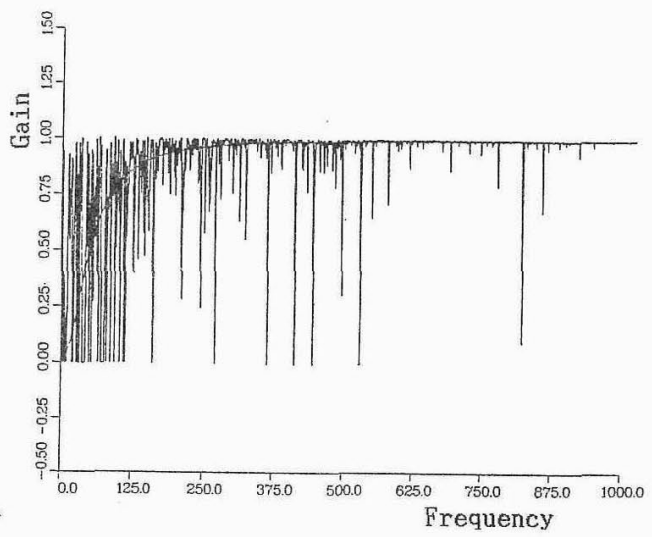

(c) Wiener filter

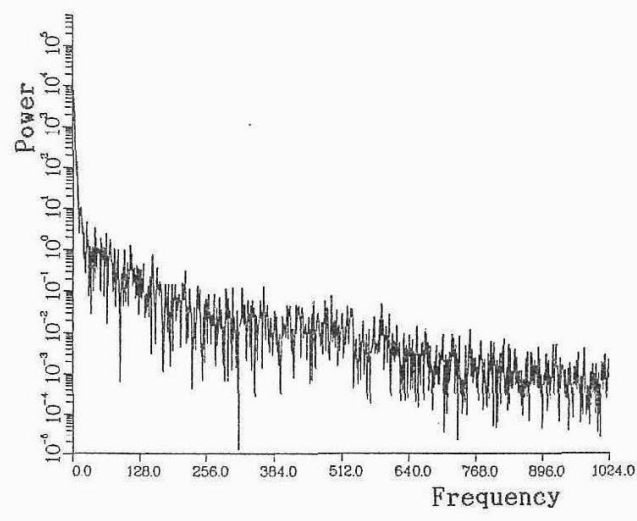

(b) power spectrum of weighted mean $m_{1}{ }^{\prime}(k)$

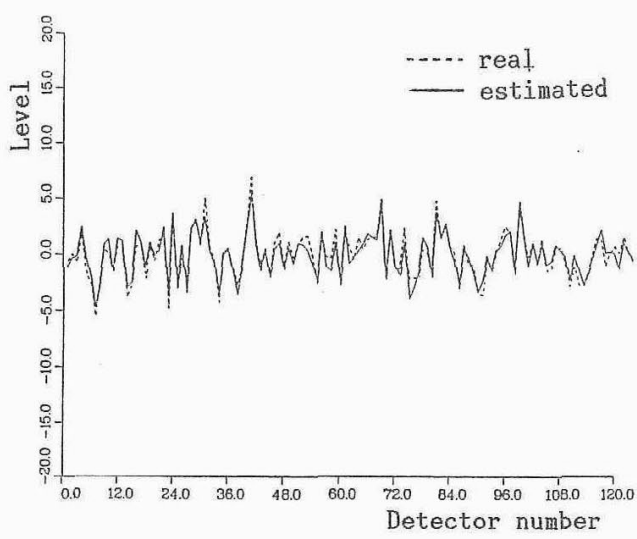

(d) estimated detector offset

Fig. 8 Estimation of detector offset

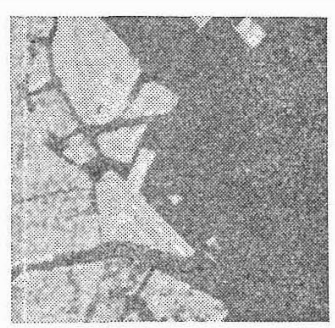

(a)

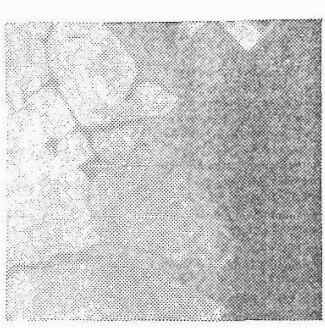

(b)
Photo. 3 Corrected image corresponding to Photo. 2

りが早い。その結果，オフセット推定精度む，Fig. 7 (d)のゲイン推定精度に比べ高いことがわかる.

このようにして推定した検出器ゲインとオフセット により，(16)式で画像データ定補正した，補正画像を Photo. 2 の決補正画像と対応させ, Photo. 3 亿示す. 原画像データとのRMS (Root Mean Square) 偏差は, 未㭪正画像の 2.03 レベルが, 補正後の画像で 0.59 レベルへと低下し，補正前の画像に見られた縦縞が消
えた．検出器の感度のばらつきを推定できたととによ り，永果のある画像補正它行えたといえる。

\section{4. おわりに}

多数の検出器が直線的に並んだリニアアレイセンサ による画像の, 検出器感度誤差に起因する縞状ノイズ の補正方式を提案した．本方式は，检出器ごとに出力 画像統計量を求め，原画像之検出器感度誤差の統計モ デルに基づくウィーナーフィルタにより，2 乘誤差最 小の意味で最邂に各検出器の感度のばらつきを推定 し，画像強度究補正するあのである，提案方式によ り，ランドサットMSS 画像定利用して作成したり ニアアレイセンサ模懝画像を補正し，その有效性を磪 かめたなお，本文では，撮像系の例として衛星撮像 システムを述べたが, 提案方式はいかなるリニアアレ イ型撮像系の㭘出器感度詰差の補正に詨しても有效で ある。

最後に，本研労を進めるにあたりご助言とご討論を 
いただいた，(株) 日立製作所システム開発研究所川崎 淳所長, 井原廣一副所長, 春名公一部長, および研究 室各位に厚く感謝の意を表します.

\section{参 考 文 献}

1) M. Chevrel, M. Courtois and G. Weill: The SPOT Satellite Remote Sensing Mission, Photogrammetric Engineering and Remote Sensing, 47-8 (1984)

2) K. Tsuchiya: Marine Observation Satellite (MOS)-1, Latin American Satellite Remote Sensing Regional User's Meeting, Sao Jose dos Campos, Brazil (1981)

3) H. Ihara, F. Komura, K. Homma, M. Kosaka, M. Takahasi and Y. Yamamoto: High Precision Modeling of Landsat Imagery Distortion, IGU Commission on Geographic Data Sensing and Processing (1980)

4) 古村, 本間 : 衛星画像処理技術, 計測之制御, 24-3, 234/ 241 (1985)

5) R. C. Gonzalez and P. Wintz: Digital Image Process- ing, Addison-Wesley Publishing Company, 218/219 (1977)

6) A. Rosenfeld and A. C. Kak: Digital Picture Processing, Academic Press, Inc. (1976)

7) 安岡, R. M. Haralick:リモートセンシング画像ピー ク雑音の除去, 国立公害 研究所報告, 第 39 号, 119/128 (1983)

8）桜井, 木村, 舆石, 倉益: 可視近赤外放射計用 CCD イメ ージセンサについて, 第 5 回りモートセンシングシンポ ジウム資料 (1979)

9) Manual of Remote Sensing: I, American Society of Photogrammetry, 776/777 (1983)

10) 本間, 坪井, 久保: リニアアレイセンサの強度補正方式, 第7 回りモートセンシングシンポジウム資料 (1981)

11) SPOT IMAGE: SPOT NEWS LETTER, Aug. (1982)

12) W. K. Pratt: Digital Image Processing, Jhon Wiley \& Sons, 20/22 (1978)

13）森下, 小畑：信号処理, (社) 計測自動制御学会, 95/97 (1982)

14) H.C. Andrews and B.R. Hunt: Digital Image Restoration, Prentice-Hall, 132/140 (1977) 